\title{
Plastic surgery in chest wall reconstruction: relevant aspects - case series
}

\section{A cirurgia plástica na reconstrução da parede torácica: aspectos relevantes - série de casos}

Diogo Franco, TCBC-RJ'; João Medeiros Tavares Filho, TCBC-RJ1; Paola Cardoso, AsCBC-RJ1; Laércio Moreto Fllho, AsCBC-

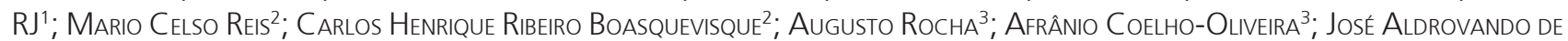
Olivelra, ECBC-RJ4; TAlita Romero Franco, ECBC-RJ'

\section{A}

\begin{abstract}
Objective: to discuss the participation of Plastic Surgery in the reconstruction of the chest wall, highlighting relevant aspects of interdisciplinaryness. Methods: we analyzed charts from 20 patients who underwent extensive resection of the thoracic integument, between 2000 and 2014, recording the indication of resection, the extent and depth of the raw areas, types of reconstructions performed and complications. Results: among the 20 patients, averaging 55 years old, five were males and 15 females. They resections were: one squamous cell carcinoma, two basal cell carcinomas, five chondrosarcomas and 12 breast tumors. The extent of the bloody areas ranged from $4 \times 9 \mathrm{~cm}$ to $25 \times 40 \mathrm{~cm}$. In 12 patients the resection included the muscular plane. In the remaining eight, the tumor removal achieved a total wall thickness. For reconstruction we used: one muscular flap associated with skin grafting, nine flaps and ten regional fasciocutaneous flaps. Two patients undergoing reconstruction with fasciocutaneous flaps had partially suffering of the flap, solved with employment of a myocutaneous flap. The other patients displayed no complications with the techniques used, requiring only one surgery. Conclusion: the proper assessment of local tissues and flaps available for reconstruction, in addition to the successful integration of Plastic Surgery with the specialties involved in the treatment, enable extensive resections of the chest wall and reconstructions that provide patient recovery.
\end{abstract}

Key words: Thoracic Wall/surgery. Breast Neoplasms/complications. Breast Neoplasms/surgery. Perforator Flap/surgery. Myocutaneous Flap/surgery.

\section{INTRODUCTION}

In the early twentieth century, surgery begins to turn into a less frightening and more reliable procedure. The three main problems were already under some control: pain, bleeding and infection. Much still lacked on the physiology and technology, but the paths were widening. Polyvalent surgeons were becoming less able to cover all diseases and all body areas, given the extent of knowledge and training required. The delicacy in handling tissue was more important than speed.

Specialties emerged and ancestral fears were overcome.

For Plastic Surgery, World War I created new circumstances. Large lesions that were previously fatal have ceased to be by the progress of medicine. It was therefore necessary to learn how to treat them. Many flaps still used today were proposed at this time. They were, however, quite empirical, lacking anatomical and physiological knowledge of the circulation of small vessels, which did not occur until the 1980s.

It was after World War II that the Thoracic Surgery became independent from general surgery, thanks to innovations originating from the needs arising from it.

To maintain ventilation during intrathoracic surgery was initially the main obstacle to opening the chest. But it was the set of advances in anesthesia, diagnostic methods, prevention and treatment of shock and infection, as well as post-operative care, that made Thoracic Surgery a well-defined specialty.

For thoracic surgeons, any strategy requires the a final competent and closed rib cage. Resection of bone structures and extensive soft tissue, where necessary, indicate the use of synthetic material or grafts, which need to be covered by well vascularized flaps.

1. Serviço de Cirurgia Plástica, Hospital Universitário Clementino Fraga Filho - Universidade Federal do Rio de Janeiro, Brasil; 2. Serviço de Cirurgia Torácica, Hospital Universitário Clementino Fraga Filho - Universidade Federal do Rio de Janeiro, Brasil; 3. Serviço de Ginecologia, Hospital Universitário Clementino Fraga Filho - Universidade Federal do Rio de Janeiro, Brasil; 4. Cirurgião Cardiovascular. 
For breast clinics, the current occurrence in Brazil of advanced tumor lesions requiring extensive resections transforms the closure of wounds in difficult problems. Even in cases attended at the appropriate time and in need of minor resections, there is demands for a good cosmetic result. The change in approach and acceptance of patients is significant: rather than mutilation, one gets breasts of nearly normal appearance, and in some cases even better than they were before.

This paper aims to discuss the participation of Plastic Surgery in the reconstruction of the chest wall, highlighting relevant aspects of interdisciplinaryness.

\section{METHODS}

We collected data from patients operated between January 2000 and October 2014 at the Hospital Universitário Clementino Fraga Filho and the Instituto de Ginecologia, both from the Universidade Federal do Rio de Janeiro (UFRJ), undergoing extensive and / or deep resections of the thoracic integument for tumor removal.

As inclusion criteria, we considered resections that reached the muscular plane (fully or partially) and had the participation of the Plastic Surgery staff in the immediate reconstruction of the thoracic wall. We excluded patients who underwent operations directly performed by Thoracic, Pediatric and Mastology surgeons without the participation of the Plastic Surgery staff.

In the analysis of treatments carried out we searched information related to the following factors: 1Indication of tumor resections: therapeutic or hygienic; 2Extension of bloody areas found after tumor resection; 3Depth of bloody areas resulting tumor resection: deep to the muscular plane or total thickness; 4- Type of reconstruction performed; and 5-Complications.

\section{RESULTS}

We evaluated the records of 20 patients. Their ages ranged from six to 82 years of age, with a mean of 55. Five patients were male and 15 were female.

All resections were indicated by the presence of tumors, with the initial diagnoses being: squamous cell carcinoma (one patient), basal cell carcinoma (two patients), chondrosarcoma (five patients), breast cancer (12 patients). The specialties associated with plastic surgery during treatment were: Pediatric Surgery (one case), Thoracic Surgery (nine cases) and Mastology (ten cases).

In four women who had extensive lesions due to locally advanced breast tumor, the proposals were hygienic resections. The other 16 patients had proposed therapeutic resections.

The extent of bloody areas ranged from $4 \times 9 \mathrm{~cm}$, in pediatric patients (age six) to $25 \times 40 \mathrm{~cm}$. Resections in 12 patients went deep until the muscular plane, with partial or complete muscle resection. In eight patients, tumor removal achieved a total wall thickness (including ribs and / or sternum).

For reconstruction of the chest wall held: one muscle flap (pectoralis major muscle) associated with skin grafting (Figure 1); nine myocutaneous flaps: transverse rectus abdominis muscle (TRAM - four cases - Figure 2); Vertical rectus abdominis muscle (VRAM - two cases Figure 3); TRAM associated with VRAM (one case - Figure 4); and latissimus dorsi muscle (two cases); and ten regional fasciocutaneous flaps (Figure 5).

Patients undergoing resection of ribs and / or sternum had the bone structure reconstructed with the use of inorganic polypropylene mesh, associated with surgical cement made of polymethyl methacrylate, to stabilize the chest movement during breathing. Two patients undergoing reconstruction with fasciocutaneous flaps sustained flap partial suffering. Since these patients had undergone reconstruction of the bone structure with alloplastic material, we chose to perform a myocutaneous flap of latissimus dorsi to cover the raw areas, with good results. In other patients there were no complications with the techniques used, requiring only one operation.

The average length of stay was 15 days, ranging from five to 47 . The minimum postoperative follow-up was three months, and the maximum, six years, with a mean 16 months. Two patients died due to the disease that caused the initial operation in the first year of postoperative followup. All flaps employed showed good aspect at the end of follow-up.

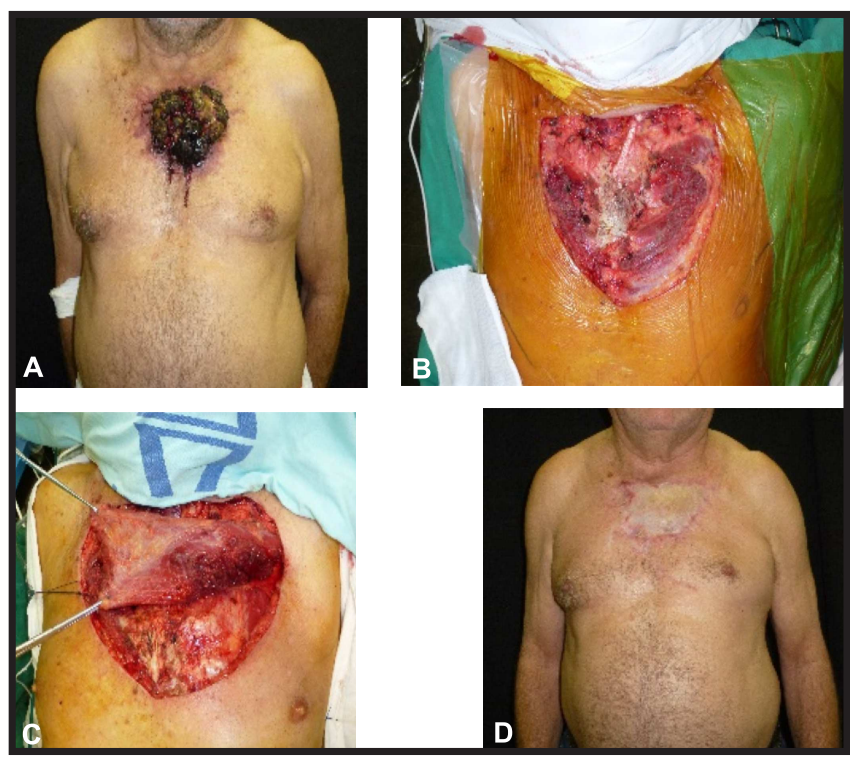

Figure 1 - A) Extensive basal cell carcinoma in the pre-sternal region. B) Bloody area with partial resection of the sternum. C) Pectoralis major muscle flap released and rotated. D) Postoperative - nine months with skin grafting on muscle flap. 


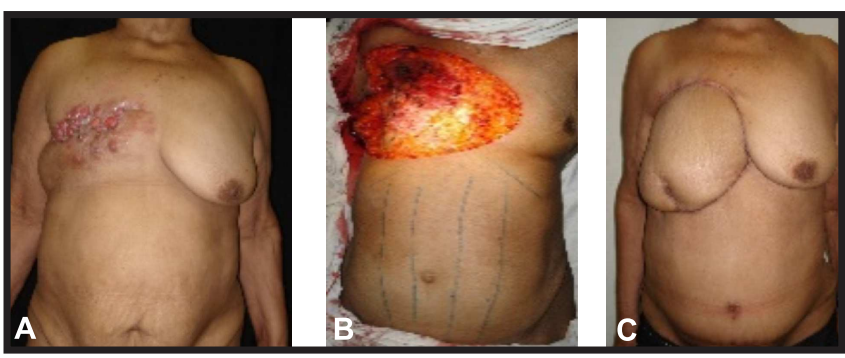

Figure 2 - A) Preoperative - recurrent breast tumor. B) Bloody Area exposing ribs. C) Three months after immediate reconstruction with transverse rectus abdominis myocutaneous flap (TRAM).

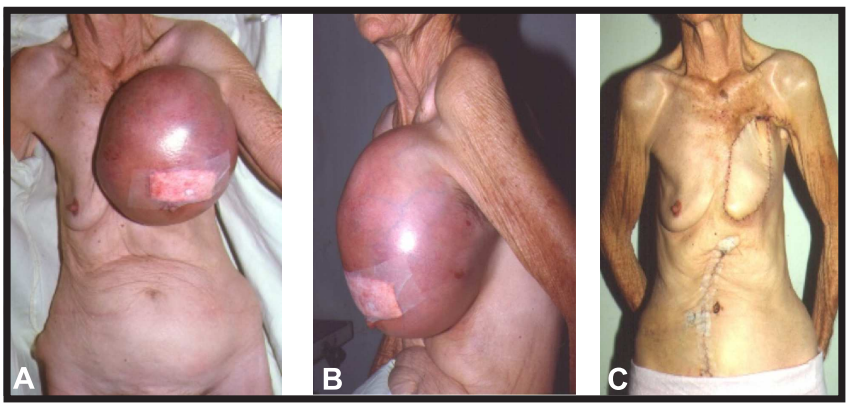

Figure 3 - A) Preoperative - chondrosarcoma. B) Profile. C) Outcome after using vertical rectus abdominis myocutaneous flap (VRAM).

\section{DISCUSSION}

The interdisciplinary treatment, regardless of disease etiology, usually brings benefits to patients, provided that the areas of action of each specialty are well-defined. Although the extent of resection should always be the one necessary and sufficient for effective treatment of the disease, the presence of a plastic surgeon at this point may allow some "negotiation" as for the structures which could be preserved without damaging treatment, but facilitating the subsequent reconstruction ${ }^{1-3}$.

For interventions on the chest wall, planning must consider: the extent of soft tissue, bone and cartilage resection; the type of material to be used for reconstruction; the well vascularized flaps available, on the surroundings or at a distance; the resources to ensure adequate pulmonary expansion; and the aesthetic concern, when possible.

These items will directly influence the choice of the type of reconstruction to be held, the extent and composition of flaps and consequently the chances of successful treatment.

The bloody area resulting from resection often exposes bone or alloplastic material, in addition to presenting mobility due to chest expansion. In these cases, thick flaps, such as myocutaneous ones, are often more appropriate and safer than fine cutaneous flaps. Different types of flaps can be used. To determine the most

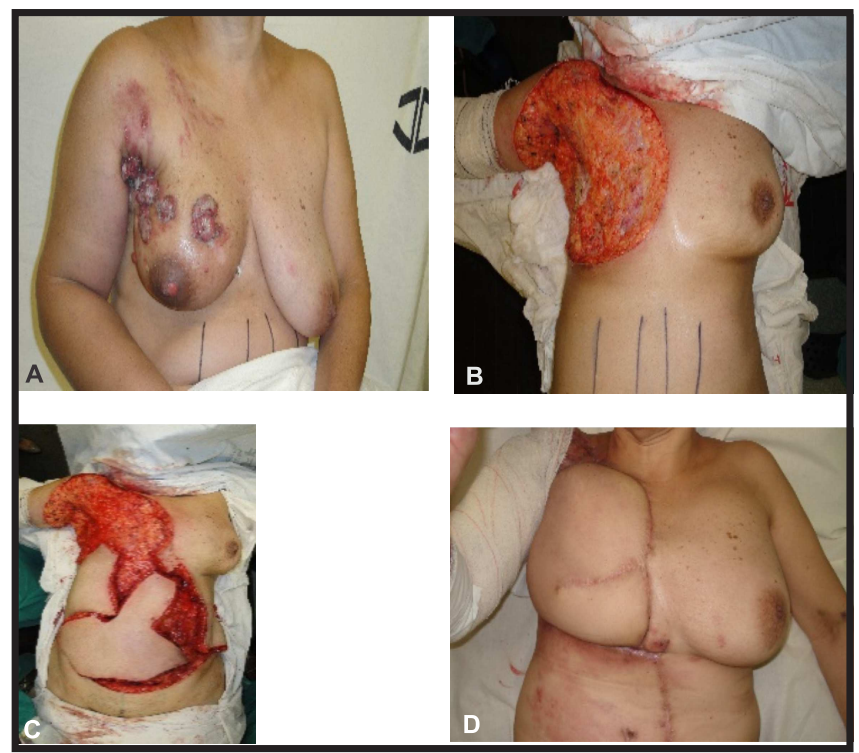

Figure 4 - $\quad$ A) Preoperative - recurrent breast tumor. B) Bloody area after tumor resection, exposing ribs. C) Association of flaps (TRAM + VRAM) ready for rotation. D) Two months after surgery.

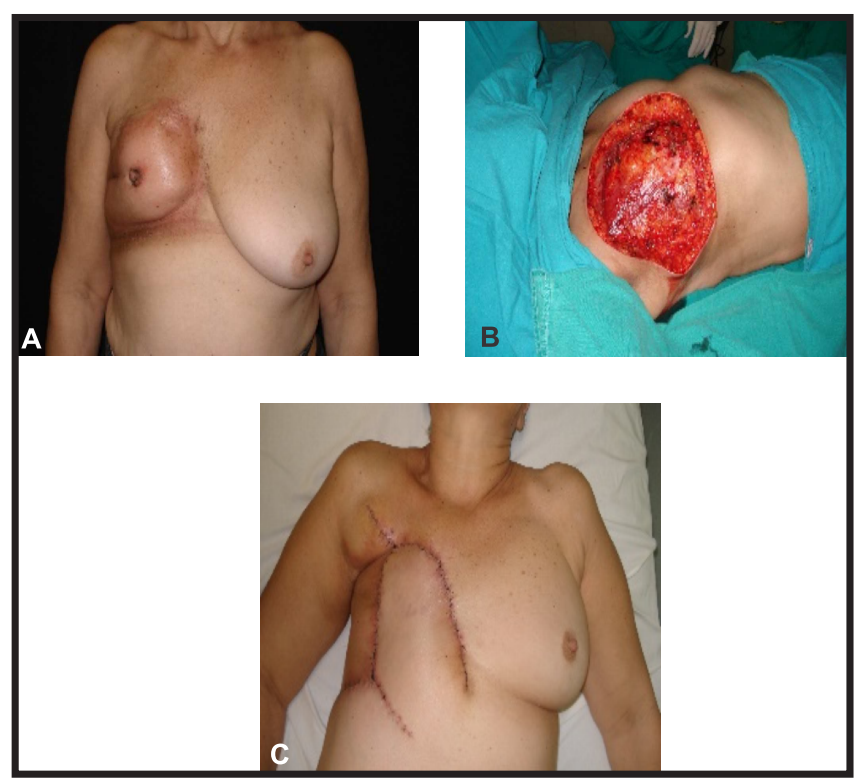

Figure 5 - A) tumor recurrence in the area of mastectomy and radiotherapy. B) Bloody area with ribs exposure. C) Follow-up after immediate reconstruction with regional fasciocutaneous flap.

appropriate, we evaluate mainly the tissues available and the needs of the bloody area. Fasciocutaneous flaps serve well for small to medium sized wounds, and when there is no alloplastic material underneath. Muscle flaps (eg pectoralis major, rectus abdominis, latissimus dorsi) bring well vascularized tissue to the reconstructed area $^{14}$. They can also attach a skin-fat segment, determining best coverage of the underlying tissue (eg transverse rectus 
abdominis muscle flap - TRAM; vertical rectus abdominis muscle flap - VRAM).

Gardner et al. Demonstrated the suitability of regional fasciocutaneous flaps in three cases, using them even on small fragments of marlex meshes, emphasizing that they should be well vascularized so there is no suffering, necrosis and destabilization of the wall ${ }^{5}$. In some situations, microsurgery flaps are indicated ${ }^{6}$, though not available in many hospitals.

There are few reports with extensive experience in the field. We highlight Arnold et al. and Mansour et al. In 1984, Arnold et al. had experience of 100 cases $^{7}$. In 66 patients there were wall resection. Most reconstructions used the pectoralis major muscle. In 1996, they described a new sequence with 500 reconstructions in 18 years of observation ${ }^{8}$. There was skeletal resection in 443 individuals. The flaps used in the reconstruction were mainly the pectoralis major and the latissimus dorsi. The average number of operations per patient was 2.3 and the length of stay was around 21 days. They also participated in other studies: on the use of alloplastic materials in stabilizing the thoracic wall9; on the characteristics of the chest wall and the usual reconstruction indications ${ }^{10}$; and on the anatomical features and surgical techniques used in the making of major muscle flaps for reconstruction ${ }^{11}$ (pectoralis major, latissimus dorsi and rectus abdominis).

Mansour et al. Presented a 25-year experience with 200 patients, analyzing surgical indications ${ }^{3}$. They found the main cause to be lung cancer, followed by chest wall cancer and breast cancer. All patients had at least two resected ribs. These defects were reconstructed with Vicryl ${ }^{\circledR}$ mesh, Prolene $₫$ mesh, or association of one of these with methacrylate (surgical cement). They employed pedicle muscle flaps in $48 \%$ of patients and microsurgical flaps in $9 \%$. The most used muscles were latissimus dorsi, pectoralis major and rectus abdominis (TRAM). The average hospital stay was 18 days and $7 \%$ of the patients died perioperatively. They questioned whether the stabilization of the wall with meshes and methacrylate would be really necessary, but employed them in all operations.

Regarding the chest wall, Makboul et al. also reported that the use of alloplastic material for structuring was not necessary, using only latissimus dorsi flaps to close the defects. However, they state that their series of five patients had undergone local radiotherapy and that this leaves the thoracic wall more rigid ${ }^{12}$. That same year, Sodha et al. encouraged the use of only acellular dermal matrix for the correction of wall defects after resection of ribs in selected cases $^{13}$. They protected the material with a latissimus dorsi flap. We emphasize that, just like these authors, we also use alloplastic material to reconstruct the wall.

Chang et al. evaluated 113 patients over a period of ten years ${ }^{14}$. The most frequent diagnoses were breast cancer, followed by sarcoma. The type of reconstruction depended on the size and location of the defect, on the rotation range of possible local flaps or on the availability of vessels for anastomoses. They recommended stabilizing the wall with alloplastic material. The most commonly used flaps were: latissimus dorsi, rectus abdominis, pectoralis major and external oblique. They used microsurgical flaps in $11 \%$ of cases. Seven patients (4\%) had partial loss of employed flaps.

In Brazil, Luz et al. presented ten cases of latissimus dorsi flap use for the closure of bloody areas after chest wall resection of advanced breast cancer ${ }^{15}$. The defects ranged from $12 \times 14 \mathrm{~cm}$ to $25 \times 25 \mathrm{~cm}$. Carvalho et al. reviewed the literature on the subject and concluded that: the flap should be chosen based on the lesion location; one needs to preserve good vascularization of the flaps; the osteocartilaginous defects must be stabilized; bone grafts have been substituted with alloplastic materials; and the prosthetic material does not increase infection rates, provided the area is well vascularised ${ }^{16}$. Tavares et al. reported two cases of omentum flap with skin autograft ${ }^{17}$. They stressed that the aesthetic result was poor, but effective. In 2014, Groth et al. described the correction of an extensive defect caused by resection of breast tumor (including wall resection) with an anterolateral thigh microsurgical flap ${ }^{18}$. Batista et al. presented a series of ten cases, highlighting the interdisciplinary work to good postoperative evolution ${ }^{19}$

Complex operations, when combined, require thorough preoperative planning, with distribution of functions and responsibilities. It is not always possible to accurately assess the extent of resection that will be required and various treatment options and flaps must be provided, with the teams prepared to perform them. After the operation, the surgeon, or someone on the staff, should accompany the patient to the recovery bed to advise on the type of decubitus to be adopted. We should point out that in many cases the discomfort is great and some positions may interfere with evolution if there is compression of the flap pedicle. Complications in the immediate postoperative period are not rare and efficient service in a timely manner is of paramount importance in achieving good results. The aesthetic concerns often make sense in the usual mastectomies and the results are highly rewarding. However, for extensive chest wall resections, the aesthetic result can be poor and will require that the patient be previously clarified in this regard.

In conclusion, the participation of Plastic Surgery in combination with these specialties made possible the treatment of extensive and complex lesions, previously considered inoperable, and facilitated postoperative outcome, patient comfort and recovery from injuries or tumors of the chest wall or the breasts.

\section{Acknowledgements}

We thank the Associate Professor, Dr. Jacir Balen, from Department of Obstetrics and Gynecology at UFRJ, for his cooperation and in recognition of his work. 
Objetivo: discorrer sobre a participação da Cirurgia Plástica na reconstrução da parede torácica, ressaltando os aspectos relevantes das associações interdisciplinares. Métodos: foram analisados prontuários de 20 pacientes submetidos a extensas ressecções do tegumento torácico, no período entre 2000 e 2014, quanto à indicação das ressecções, à extensão e à profundidade das áreas cruentas, aos tipos de reconstruções realizadas e às complicações. Resultados: entre os 20 pacientes, com média de 55 anos de idade, cinco eram do sexo masculino e 15 do feminino. Foram ressecados: um carcinoma espinocelular, dois carcinomas basocelulares, cinco condrossarcomas e 12 tumores de mama. A extensão das áreas cruentas variou de $4 \times 9 \mathrm{~cm}$ até $25 \times 40 \mathrm{~cm}$. Em 12 pacientes as ressecções abrangeram o plano muscular. Nos oito restantes, a retirada do tumor atingiu a espessura total da parede. Para reconstrução foram utilizados: um retalho muscular associado à enxertia de pele, nove retalhos miocutâneos e dez retalhos fasciocutâneos da região. Em dois pacientes submetidos à reconstrução com retalhos fasciocutâneos houve sofrimento parcial do retalho, resolvido com o emprego de retalho miocutâneo. Nos outros pacientes não houve intercorrências com as técnicas empregadas, sendo necessária somente uma cirurgia. Conclusão: a adequada avaliação dos tecidos locais e dos retalhos disponíveis para a reconstrução, além da boa integração da Cirurgia Plástica com as especialidades envolvidas no tratamento, possibilitam extensas ressecções da parede torácica e reconstruções que propiciam a recuperação do paciente.

Descritores: Parede Torácica/cirurgia. Neoplasias da Mama/complicações. Neoplasias da Mama/cirurgia. Retalho Perfurante/ cirurgia; Retalho Miocutâneo/ cirurgia.

\section{REFERENCES}

1. Cohen M, Ramasastry SS. Reconstruction of complex chest wall defects. Am J Surg. 1996;172(1):35-40.

2. Hodgkinson DJ, Arnold PG. Chest-wall reconstruction using the external oblique muscle. Br J Plast Surg. 1980;33(2):216-20.

3. Mansour KA, Thourani VH, Losken A, Reeves JG, Miller JI Jr, Carlson GW, et al. Chest wall resections and reconstruction: a 25-year experience. Ann Thorac Surg. 2002;73(6):1720-5; discussion 17256.

4. Molitor M, Simek M, Lonsk $\square$ V, Kaláb M, Vesel $\square$ J, Zále $\square$ ák B. Pectoral muscle flap with $\mathrm{V}-\mathrm{Y}$ skin paddle for covering sternal defects. Ann Thorac Surg. 2012;94(5):e131-3.

5. Gardner B, Shin H, Alfonso A. Repair of large chest wall defects using pedicle flaps. Am J Surg. 1976;132(3):406-9.

6. Dast S, Berna P, Qassemyar Q, Sinna R. A new option for autologous anterior chest wall reconstruction: the composite thoracodorsal artery perforator flap. Ann Thorac Surg. 2012;93(3):e67-9.

7. Arnold PG, Pairolero PC. Chest wall reconstruction. Experience with 100 consecutive patients. Ann Surg. 1984;199(6):725-32.

8. Arnold PG, Pairolero PC. Chest wall reconstruction: an account of 500 consecutive patients. Plast Reconstr Surg. 1996;98(5):80410.

9. Deschamps C, Tirnaksiz BM, Darbandi R, Trastek VF, Allen MS, Miller DL, et al. Early and long-term results of prosthetic chest wall reconstruction. J Thorac Cardiovasc Surg. 1999;117(3):588-91; discussion 591-2.

10. Clemens MW, Evans KK, Mardini S, Arnold PG. Introduction to chest wall reconstruction: anatomy and physiology of the chest and indications for chest wall reconstruction. Semin Plast Surg. 2011:25(1):5-15.

11. Bakri K, Mardini S, Evans KK, Carlsen BT, Arnold PG. Workhorse flaps in chest wall reconstruction: the pectoralis major, latissimus dorsi, and rectus abdominis flaps. Semin Plast Surg. 2011;25(1):4354.

12. Makboul M, Salama Ayyad MA. Is myocutaneous flap alone sufficient for reconstruction of chest wall osteoradionecrosis? Interact Cardiovasc Thorac Surg. 2012;15(3):447-51.
13. Sodha NR, Azoury SC, Sciortino C, Sacks JM, Yang SC. The use of acellular dermal matrices in chest wall reconstruction. Plast Reconstr Surg. 2012;130(5 Suppl 2):175S-82S

14. Chang RR, Mehrara BJ, Hu QY, Disa JJ, Cordeiro PG. Reconstruction of complex oncologic chest wall defects: a 10-year experience. Ann Plast Surg. 2004;52(5):471-9; discussion 479.

15. Luz DP, Lobo CAH, Hiraki P, Okada A, Montag E, Ferreira MC. Retalho miocutâneo de latíssimo do dorso em V-Y para reconstrução de grandes defeitos torácicos extensos. Rev Bras Cir Plást. 2010;25(3 Supl):64.

16. Carvalho MVH; Rebeis EB, Marchi E. Reconstrução da parede torácica nos defeitos adquiridos. Rev Col Bras Cir. 2010;37(1):649.

17. Oliveira-Tavares FM, Menezes CMGG, Moscozo MVA, Xavier GRS, Oliveira GMO, Amorim Jr MAP, et al. Retalho de omento: uma alternativa em cirurgia reparadora da parede torácica. Rev Bras Cir Plást. 2011;26(2):360-5

18. Groth AK, Silva ABD, Maluf Júnior I, Ono MCC, Faris NA, Chociai AC. A versatilidade do retalho anterolateral da coxa em reconstruções oncológicas: série de casos do Serviço de Cirurgia Plástica Reconstrutora e Microcirurgia do Hospital Erasto Gaertnera. Rev Bras Cir Plást. 2014;29(1):176-8.

19. Batista KT, Araujo HJ, Mammare EM, Aita AA, Silva RS. Reconstrução da parede torácica após a ressecção de extensos tumores. Rev Bras Cir Plást. 2014;29(4):550-6.

Received at: 12/03/2015

Accepted for publication: 30/05/2015

Conflict of interest: none.

Source of funding: none.

\section{Mailing address:}

Diogo Franco Vieira de Oliveira

E-mail: contato@diogofranco.com 